Apidologie, 1983, 14 (2), 127-135

\title{
ORGANISATION SPATIALE DU SYSTÈME NERVEUX ANTENNAIRE DE L'ABEILLE ÉTUDIÉE AU MOYEN D'UNE TECHNIQUE DE MARQUAGE AUX IONS COBALT
}

\author{
Gérard ARNOLD, Claudine MASSON et Sati BUDHARUGSA
}

Laboratoire de Neurobiologie Sensorielle de l'Insecte I.N.R.A. - C.N.R.S. (CNRS, ERA 740)

Station de Recherches sur l'Abeille et les Insectes sociaux 91440 BURES SUR YVETTE

\section{RÉSUMÉ}

Nous présentons ici la mise au point chez l'abeille d'une méthode neuroanatomique appliquée à l'étude de l'organisation de la voie afférente antennaire par migration axonale passive d'ions cobalt. Des résultats préliminaires sont donnés à titre d'illustration.

\section{INTRODUCTION}

Les recherches que nous poursuivons sur l'abeille visent à analyser, dans des buts à la fois fondamentaux et appliqués, les mécanismes à la base des systèmes de communication chimique, aussi bien intraspécifiques (par les phéromones) qu'interspécifiques (par les allomones et/ou les kairomones), par l'utilisation conjointe d'approches expérimentales complémentaires : comportementales (PHAM et MASSON, 1982), neurophysiologiques (MASSON, 1982; ARNOLD et MASSON, 1980) et anatomiques (MASSON, 1982; ARNOLD et MASSON, 1981, 1983).

Dans cette courte note sont rapportées uniquement les données relatives à la mise au point sur l'abeille d'une méthode d'analyse neuroanatomique appliquée à l'étude de l'organisation de la voie afférente antennaire. Quelques résultats préliminaires sont présentés à titre d'illustration.

Les milliers de sensilles, en majorité olfactives, de l'antenne d'ouvrière sont innervées chacune par plusieurs neurones sensoriels. Par conséquent quelques dizaines de milliers d'axones sensoriels par antenne, vont transmettre les informations chimiques de l'environnement jusqu'au cerveau où elles seront traitées et intégrées (MASSON et Brossut, 1981). Ces axones constituent la partie sensorielle du 
nerf antennaire et sont distribués au niveau du premier relais de la voie afférente antennaire, le deutocérébron, où ils convergent sur les terminaisons des ramifications dendritiques de quelques milliers de deutoneurones avec lesquels ils entrent en contacts synaptiques au niveau d'aires neuropilaires caractéristiques, les glomérules; ces structures identifiables sont donc induites par la convergence du système (MAsson, 1972, 1977, chez la fourmi et la guêpe; PAReto, 1972 et Suzukı, 1975, chez l'abeille).

Au sein de la population des deutoneurones on distingue deux types de cellules, d'une part les interneurones locaux strictement confinés à l'étage deutocérébral, d'autre part les deutoneurones dits « relais » dont les axones se dirigent vers d'autres centres nerveux.

Il va donc de soi que pour comprendre les bases du fonctionnement de l'ensemble du système olfactif, il est indispensable de connaître parfaitement l'organisation de cet étage chez l'adulte et d'analyser finement la mise en place de la connectivité entre les neurones impliqués (donc des glomérules) au cours de l'ontogénèse, pendant le développement nymphal.

\section{MATÉRIEL}

La mise au point de la technique de marquage a été effectuée sur des abeilles de race italienne Apis mellifica ligustica $\mathrm{L}$. dont les colonies ont été génétiquement homogénéisées par insémination artificielle des reines avec le sperme de leurs fils ou de leurs frères de façon à obtenir des ouvrières ayant un coefficient de parenté élevé $(0,75$ à 0,875 dans les travaux effectués ici).

Les expériences ont porté à la fois sur des abeilles adultes (ouvrières et mâles) et au cours du développement post embryonnaire sur des nymphes d'ouvrières.

Afin de disposer de nymphes d'âge parfaitement connu, nous avons maintenu une des reines inséminées artificiellement, pendant 24 heures, sur un rayon vide de tout couvain sur lequel elle a pondu. A partir du $12^{e}$ jour après la ponte de l'œuf, la métamorphose ayant eu lieu, des nymphes d'âge identique ont été prélevées quotidiennement et étudiées d'un point de vue structural.

\section{MÉTHODE}

\section{- Principe}

La topographie des projections des afférences antennaires est analysée à partir de marquages cellulaires effectués par applications de chlorure de cobalt à une extrémité sectionnée d'une des deux antennes de l'animal vivant; les ions cobalt effectuent une migration axonale passive depuis la périphérie du système jusqu’à leurs cibles dans le système nerveux central (TYrer et ALTMAN, 1974). On admet généralement - bien que le principe exact ne soit pas encore connu - que les ions cobalt franchissent la fente synaptique entre les neurones successifs selon un processus « d'uptake " membranaire localisé au niveau du neurone postsynaptique (STRAuSFELD et OBermaYer, 1976), ce qui permet de suivre histologiquement le trajet de l'information afférente.

- Protocole

Chaque abeille (nymphe ou adulte) est immobilisée et maintenue à l'étuve à $33 \circ \mathrm{C}$ pendant toute la 
durée de migration du cobalt. L'antenne droite et le système afférent droit font l'objet de l'analyse, les cinq articles distaux du funicule antennaire étant sectionnés; l'antenne gauche et le système afférent gauche restant intacts serviront de référence. Un tube cathéter empli d'une solution de chlorure de cobalt à $5 \%$ dans du Ringer pour abeille vient coiffer l'extrémité sectionnée de l'antenne.

La migration axonale passive s'effectue pendant 16 heures à la température de 33 oC ou à la température ambiante; elle est suivie d'une rapide prédissection effectuée dans le Ringer. Le cerveau est alors plongé pendant 4 minutes dans une solution de sulfure d'ammonium qui provoque un précipité noir de sulfure de cobalt. Cette opération est suivie de plusieurs rinçages au Ringer, de la dissection fine des tissus nerveux et de la fixation par le Bouin alcoolique. Après déshydratation les pièces sont orientées et incluses dans du polywax à $57 \circ \mathrm{C}$; les coupes sériées de 5 à $7 \mu \mathrm{m}$ sont colorées sur lames selon la méthode de TIMm (TYRER et BeLL, 1974) qui permet de contraster les structures marquées au sulfure de cobalt au moyen d'une intensification par les sels d'argent. Les analyses des coupes histologiques sont effectuées directement au microscope optique et sur clichés photographiques à divers grossissements.

\section{RÉSULTATS PRÉLIMINAIRES ET DISCUSSION}

L'application d'une telle méthode à l'abeille s'est révélée fructueuse puisqu'elle a permis, d'une part d'analyser chez l'adulte (ouvrière et mâle), les cibles de projection des axones sensoriels dans le système nerveux central et, d'autre part d'étudier chez les nymphes d'ouvrières la mise en place temporelle des connexions synaptiques entre les neurones sensoriels et les deutoneurones. Les résultats ainsi obtenus sont publiés en détail par ailleurs (ARNOLD et MASSON, 1983; ARNOLD et al., 1983; Masson, 1982).

\section{Chez l'adulte}

\section{- Ouvrière (voir figure 1)}

L'organisation générale du lobe antennaire du deutocérébron est tout à fait comparable à celle décrite chez les insectes sociaux (abeilles, guêpes et fourmis) en utilisant d'autres méthodes de coloration du système nerveux. Les axones du nerf antennaire ont été sélectivement marqués par les ions cobalt et sont colorés en noir après intensification. Ils se dirigent vers les glomérules où ont lieu les synapses avec les deutoneurones qui sont donc également marqués par le cobalt. La structure des glomérules est tout à fait caractéristique avec une couche corticale fortement colorée où sont réparties les connexions synaptiques; ils sont de forme ovoïde et de volume assez homogène.

Les axones des deutoneurones relais sont également marqués en noir, ce qui permet de visualiser directement leurs trajets jusqu'à leurs cibles de projections dans d'autres régions du système nerveux central (protocérébron et ganglion sous-œsophagien).

C'est essentiellement au niveau de l'analyse de la distribution spatiale de ces axones des neurones de deuxième ordre que la technique de marquage au cobalt décrite a permis d'apporter des données intéressantes et nouvelles comparées à celles 
précédemment publiées. C'est ainsi qu'a été mise en évidence une voie deutocérébrale contralatérale constituée d'un faible nombre de fibres. Il a en outre été possible de mettre en évidence l'existence d'un faisceau direct entre le deutocérébron et le lobe latéral du protocérébron qui vient renforcer l'hypothèse du rôle important que semble jouer cette region du protocérébron dans le traitement des messages olfactifs. Ces résultats sont détaillés et illustrés par ailleurs (ARNOLD et al., 1983).
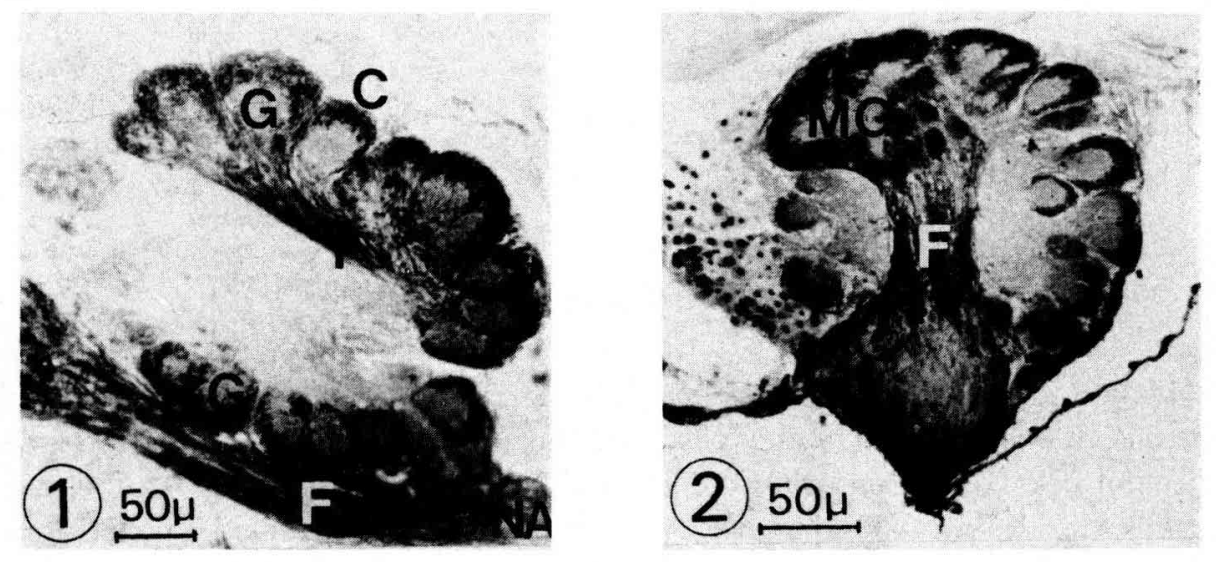

FIG. 1. - Coupe sagittale dans le deutocérébron d'une ouvrière adulte.

Le cobalt a migré le long des axones du nerf antennaire (NA) qui sont colorés en noir. Cette technique permet de mettre en évidence la topographie des différents faisceaux (F) et des cibles de projections des axones sensoriels dans la zone corticale (C) des glomérules $(G)$, où ont lieu les connexions synaptiques avec les dendrites des deutoneurones.

FIG. 1. - Sagittal section of the deutocerebrum in an adult worker.

There is a passive migration of cobalt ions along the axons of the antennal nerve (NA) which are black stained. This technic allows to show the topography of the different branches $(F)$ and of the central targets of the sensory axons in the cortical layer (C) of the glomeruli $(G)$, where take place the synaptic connexions with the dendrites of the deutoneurons.

FIG. 2. - Coupe frontale dans le deutocérébron d'un mâle adulte.

Il existe chez le mâle des glomérules hypertrophiés (ou complexe macroglomérulaire : MG) qui sont très vraisemblablement le lieu de projection des informations phéromonales.

FiG. 2. - Frontal section of the deutocerebrum in an adult drone.

In drones, there are macroglomeruli (MG) which are very likely the sites of primary projection of pheromonal messages.

\section{- Mâle (voir figure 2)}

Notre analyse a pour l'instant principalement porté sur l'organisation spatiale des glomérules. Il apparaît que leurs formes et dimensions sont beaucoup moins homogènes que chez l'ouvrière.

Nous avons pu également mettre en évidence l'existence de trois masses sphériques de dimensions importantes constituées chacune de sous-unités glomérulaires. Ces structures particulières doivent correspondre à ce qui a été récemment 
décrit sous le terme de " macroglomérule » ou de " complexe glomérulaire » chez d'autres espèces d'insectes (BоEсKн et al., 1977; ChAMBILle et al., 1980; Hildebrand et al., 1980) et qui représente un dimorphisme sexuel où les informations sexuelles émises par la femelle de l'espèce sont spécifiquement traitées (MASSON et BrosSUT, 1981).

\section{Chez la nymphe}

La méthode a permis d'analyser directement, au niveau spatial, le décours temporel de la mise en place des synapses entre les axones des neurones sensoriels et les dendrites des deutoneurones (figurées par les glomérules deutocérébraux). En effet, comme l'ont récemment montré BASSEMIR et STRAUSFELD (1983), les ions cobalt franchissent les synapses et sont récupérés par les neurones postsynaptiques dans lesquels ils continuent leur migration.

C'est à partir du troisième jour de la période nymphale que les premières connexions apparaissent. L'organisation spatiale des glomérules est comparable à celle de l'insecte adulte dès le septième jour de la vie nymphale, c'est-à-dire trois jours avant l'émergence.

\section{INTÉRÊT DE LA MÉTHODE}

Utilisé en migration axonale passive, le chlorure de cobalt permet d'obtenir à partir d'une application périphérique localisée au niveau de l'antenne sur l'animal vivant des marquages sélectifs de la voie afférente à ses divers étages du système nerveux central.

Le fait que les ions cobalt traversent les synapses conduit à une visualisation globale du système beaucoup plus complète que les autres techniques précédemment utilisées, telles par exemple ia dégénérescence sélective (PARETO, 1972) ou l'injection d'une substance fluorescente (SUZUKı, 1975).

L'analyse plus fine des neurones individualisés et de leurs processus nerveux demande un marquage cellulaire sélectif; nous appliquons actuellement à l'abeille une telle méthode mise au point pour l'analyse du système visuel de la mouche (STRAUSFEld et HAUSEN, 1977), en injectant directement, à l'aide d'une micropipette, le chlorure de cobalt dans le neuropile deutocérébral. L'utilisation conjointe de ces deux méthodes de marquage semble devoir conduire à une description fine de la connectivité des réseaux neuroniques impliqués dans le traitement des informations olfactives antennaires dont nous analysons simultanément les caractéristiques fonctionnelles chez l'abeille. 


\section{REMERCIEMENTS}

Les auteurs remercient vivement d'une part M. Jean Theurkauff de la Station de Recherches sur l'Abeille et les Insectes sociaux à Bures sur Yvette, d'autre part M. Jean FresNAYE de la Station Expérimentale d'Apiculture, INRA, 84140 MONTFAVET, pour les aides précieuses qu'ils ont apportées dans l'obtention du matériel biologique génétiquement homogénéisé.

\section{SPATIAL ORGANIZATION OF THE SENSORY ANTENNAL SYSTEM IN THE BEE BY USING A COBALT IONS MARKING METHOD}

\section{INTRODUCTION}

Our basic and applied research on the bee was developed to understand the neural basis of intraspecific (pheromones) and interspecific (allomones, kairomones) chemical communication, using combined and complementary experimental methods : behavioural (PHAM and MASSON, 1982) neurophysiological (MASSON, 1982; ARNOLD and MASSON, 1980) and anatomical (ARNOLD and MASSON, 1981, 1982; MASSON, 1982).

In this note we are reporting preliminary data related to the adjustment of a neuroanatomical marking method for the study of the organization of the antennal afferent pathways of the honeybee.

Each of the thousands of antennal sensilla (mainly olfactory) housed several sensory cells. Thus, tens of thousands of sensory axons per antenna translate the chemical messages of the insect environment to its brain where they are processed and integrated (MAsson and Brossut, 1981). These axons constitute the sensory part of the antennal nerve and are distributed directly to the first central relay of the afferent pathway, the deutocerebrum. There they converge by means of synaptic connections onto the dendritic processes of some thousands of deutoneurons at the level of specialized neuropilar areas : the glomeruli. These identifiable structures are therefore induced by the huge convergence of the afferents onto the efferent fibres (MAsson, 1972, 1977 in ants and wasps; PARETO, 1972 and SuzuKI, 1975, in honeybees).

Two types of deutoneurons are functionally identifiable : the local interneurons strictly confined to the deutocerebral level and the output deutoneurons or relay deutoneurons, whose axons are going towards the other specific regions of the central nervous system.

To understand the basic functional mechanisms of the olfactory system, it is necessary to know, as well as possible, the general anatomy of this level in the adult, and to analyze in detail the successive steps of the connectivity between the neuronal network (the steps of the development and mapping of the glomeruli) in the course of ontogeny, during the pupal development.

\section{INSECTS}

The animals used for the present investigation were adult workers and drones, and pupae of Apis mellifica ligustica $\mathrm{L}$. To obtain workers with a high coefficient of relationship $(0,75$ and 0,875$)$ the colonies were genetically homogenized by artificial insemination.

To obtain known age pupae, we allowed the queen to lay in an empty comb for 24 hours. Pupae were taken daily 12 days after egg-laying.

\section{METHOD}

Principle. The topography of the antennal afferent pathways has been studied by cellular marking following localized application with cobalt chloride to the cut end of one antenna of a living bee.

There is a passive migration of cobalt ions along the neurons from the periphery to their targets in the central nervous system (TYRER and ALTMAN, 1974). One generally admits that the cobalt ions cross 
the synaptic cleft according to an uptake located in the postsynaptic neuron (STRAUSFI.D and OBERMAYER, 1976).

Experimental schedule. Insects (adult and/or pupa) are fixed in position and kept in an incubator at $33 \mathrm{oC}$. The five distal segments of the right antenna are excised and the undamaged left antenna is used as a control. A catheter tube filled with cobalt chloride ( $5 \%$ in Ringer) is used to cover the cut antenna. The filling is accomplished in about $16 \mathrm{~h}$ at $33 \circ \mathrm{C}$ or at room temperature. Then, the brain is quickly and crudely dissected in Ringer solution and the cobalt ions are converted to cobalt sulfide (black precipitate) by immersing the brain in ammonium sulfide for $4 \mathrm{mn}$. After several rinsings in Ringer, the brain is finely dissected and fixed in alcoholic Bouin. Then, the pieces are dehydrated and embedded in polywax at $57{ }^{\circ} \mathrm{C}$. The serial sections $(5-7 \mu \mathrm{m}$ ) are intensified following the Timm's sulfide silver method (TYRER and BELL, 1974). The histological sections are then examined with a light microscope and on photographic plates.

\section{PRELIMINARY DATA AND DISCUSSION}

The development and the application of this method to the honeybee has been very fruitful. Thus, it has been possible to analyse in the adult (worker and drone) the different central targets of the sensory axons and to study the temporal setting up of the synaptic connections between the sensory neurons and the deutoneurons during the pupal development of the worker. The detailed results are described elsewhere (ARNOLD and MASSON, 1982; MASSON, 1982; ARNOLD et al., 1983).

\section{Adults}

Worker: The general organization of the antennal lobe is closely similar to the description given for social insects (honeybees, waps, ants) but using other marking techniques. The axons of the antennal nerve were selectively filled by cobalt ions and stained black after intensification. They reach the glomeruli and contact the deutoneurons which are also labelled by the cobalt. The glomeruli are very typical, they have a darkly stained cortical layer where the synapses occurs, they are egg-shaped and their volumes are relatively homogeneous (Figure 1).

The axons of the output deutoneurons are also stained black, and they can be traced to the different centres in the brain (protocerebrum and suboesophageal ganglion).

This cobalt chloride staining technique has been especially fruitful for mapping the second order neurons. By use of this technique a thin contralatera tractus in the deutocerebrum has been displayed. A newly demonstrated direct bundle from the deutocerebrum to the lateral protocerebral lobe support the hypothesis that this area is crucial for the processing of the olfactory informations. These results are detailed and illustrated elsewhere (ARNOLD et al, 1983).

Drones: The spatial organization of the drone glomeruli, show that their shapes and sizes are less homogeneous than they are in the workers. Also, two large spherical structures composed of glomerular subunits have been demonstrated (Figure 2). They are certainly equivalent to the similar structures identified in other insects, called " macroglomerulus " or " macroglomerular complex " (BOECKH et al., 1977; Chambille et al., 1980; Hildebrand et al., 1980), which are sexually dimorphic areas, where the chemical messages emitted by the female are mainly integrated (MASSON et BrossuT, 1981).

Pupae: This method has allowed a direct spatial analysis of the temporal setting up of the synaptic connections between the sensory axons and the dendrites of the deutoneurons (at the level of the glomeruli).

As recently demonstrated by BASSEMIR and STRAUSFELD (1983) cobalt ions cross the synapses and are recovered by the postsynaptic neurons where they continue their migration. The first connections appear on the 3 rd day of the pupal period. The general spatial organization of the glomeruli is very similar to that of the normal adult on the 7 th day of the pupal period (i.e. 3 days before emergence).

\section{INTEREST OF THE METHOD}

Used in passive axonal transport, the cobalt chloride dye can be applied to a localized area of the antenna of the living insect as a selective marker for the afferent pathway at various steps in the central nervous system. 
The cobalt ions cross the synapses and lead to a general overview of the system more complete than previously described by using other methods, as for example the selective degeneration (PARETO, 1972) or the injection of a fluorescent dye (Suzuk I, 1975).

A more detailed description of individualized neurons and their processes require a selective filling for each cell. To reach this goal, we are now modifying for the honeybees a method previously developed for the study of the visual system of the fly (STRAUSFELD and HAUSEN, 1977). We inject cobalt ions directly in the deutocerebral neuropile with a micropipette. By combining these two methods we hope to obtain in the near future a very precise description of the relationship between the neuronal networks involved in the processing of the antennal olfactory informations which we analyzed simultaneously the functional characteristics in the honeybee.

Reçu pour publication en novembre 1982 Eingegangen im November 1982

\section{BIBLIOGRAPHIE}

ARNOLD G., MASSON C., 1980. - Postnatal maturation of the olfactory system in the worker bee; effects of early social deprivation. Olfaction and Taste VII., van der Starre ed. IRL London, 279.

ArNold G., Masson C., 1981. - Évolution, en fonction de l'âge, de la structure externe des sensilles olfactives de l'antenne de l'ouvrière d'abeille Apis mellifica L. C.R.Acad. Sc. Paris, 292, 681-686.

Arnold G., Masson C., 1983. - Mise en place des connexions synaptiques de la voie afférente antennaire au cours du développement nymphal de l'ouvrière d'abeille Apis mellifica L. C.R. Acad. Sc. Paris, D, 296, 131-135.

arnold G., Masson C., Budharugisa S., 1983. - Étude comparée du premier relais de la voie afférente antennaire, le deutocérébron, chez l'ouvrière et le mâle d'abeille. (Soumis pour publication à Int.J. Insect Morphol et Embryol.)

Bassemir U.K., Strausfeld N.J., 1983. - Fine structural basis of cobalt coupling between neurons. In Symposium « Neurobiology », Soc. for Exper. Biol., Bristol, Angleterre.

Bоескн J., Bоескн V., KÜn A., 1977. - Further data on the topography and physiology of central olfactory neurons in insects. Olfaction and Taste VI. Le Magnen ed. IRL London, 315-321.

Chambille I., Masson C., Rospars J. P., 1980. - The deutocerebrum of the cockroach Blaberus craniifer Burm. Spatial organization of the sensory glomeruli. J. Neurobiol. 75, 135-157.

Hildebrand J. G., Matsumoto S. G., Camazine S. M., Tolbert L.P., Blank S., Ferguson H. et Ecker V., 1980. - Organization and physiology of antennal centres in the brain of the moth Manduca sexta. In Insect neurobiology and pesticide action (Neurotox, 1979) Society for Chemical Industry, London, 375-382.

Masson C., 1972. - Le système antennaire chez les fourmis. Z. Zellforsch., 134, $31-64$.

Masson C., 1977. - Central olfactory pathways and plasticity of responses to odorous stimuli in insects. Olfaction and Taste VI. Le Magnen ed. IRL London, 305-314.

Masson C., 1982. - Basic mechanisms of sensory antennal information processing in insects, with special reference to social insects. In The Biology of Social Insects, Breed ed., Westview Press, Boulder, 380-384.

Masson C., Brossut R., 1981. - La communication chimique chez les insectes. La Recherche, 121, 406-416.

Pareto A., 1972. - Die zentrale Verteilung der Fühlerafferenz bei Arbeiterinnen der Honigbiene. $Z$. Zellforsch., 131, 109-140.

Pham-Delegue M. H., Masson C.,, 1982. - Étude par conditionnement associatif de l'attraction des abeilles par les arômes végétaux. Bull. Soc. Entomol. Fr. (sous Presse).

Strausfeld N.J., HAUSEN K, 1977. - The resolution of neuronal assemblies after cobalt injection into neuropil. Proc. R. Soc. London, B, 199, 463-476. 
Strausfeld N. J., Obermayer M., 1976. - Resolution of intraneuronal and transsynaptic migrations of cobalt in the insect visual and central nervous systems. I. Comp. Physiol., 110, 1-12.

Suzukı H., 1975. - Antennal movements induced by odour and central projection of the antennal neurones in the honeybee. J. Insect Physiol., 21, 831-847.

Tyrer N. M., AltMan J. S., 1974. - Motor and sensory flight neurons in a locust demonstrated using cobalt chloride. J. Comp. Neurol., 157, 117-138.

Tyrer N. M., Bell E. M., 1974. - The intensification of cobalt-filled neurone profiles using a modification of Timm's sulphide-silver method. Brain Res., 73, 151-155. 